\title{
New taxon of the genus Calypogeia (Jungermanniales, Hepaticae) in Poland
}

\author{
Katarzyna Buczkowska*, Alina Bączkiewicz \\ Institute of Experimental Biology, Adam Mickiewicz University, Umultowska 89, 61-614 Poznań, Poland
}

\section{Abstract}

Genetic differentiation of Calypogeia muelleriana s.l. was studied using isozyme analysis. Two forms of this species: typical and atypical were reported from Poland. The 10 putative loci in 7 enzyme systems were analyzed in 58 samples: 34 of the typical and 15 of atypical form. The isozyme studies revealed that the typical and atypical forms of C. muelleriana in Poland are clearly genetically different. Typical plants morphologically correspond to the type specimen of $C$. muelleriana, but atypical form is a new, genetically distinct but unrecognized so far taxon. Each group is defined by several fixed alleles present in all populations. The UPGMA dendrogram based on Nei's genetic distances shows that both taxa (C. muelleriana and the newly detected taxon) clearly differ from $C$. azurea - the species used as a reference group. Genetic distance among two groups of $C$. muelleriana $(D=1.093)$ was almost the same as among $C$. azurea and the newly detected taxon $(D=1.060)$. Genetic distance among $C$. azurea and the typical form of $C$. muelleriana was the lowest $(D=0.628)$.

Keywords: Bryophyta, liverworts, Calypogeia, isozyme patterns, genetic distance, new taxon

\section{Introduction}

The genus Calypogeia Raddi comprises about 90 described species distributed worldwide, with the highest diversity of species observed in tropics [1,2]. In Europe, Calypogeia is represented by only nine species: $C$. azurea Stotler \& Crotz, $C$. integristipula Steph., C. neesiana (C. Massal. \& Carestia) Müll. Frib., C. suecica (Arnell \& J. Perss.) Müll.Frib., C. muelleriana (Schiffn.) Müll. Frib., C. sphagnicola (Arnell \& J. Perss.) Warnst. \& Loeske, C. fissa (L.) Raddi, C. arguta Nees \& Mont. and C. azorica Bischl. (the latter endemic for the Azores) [2,3]. All European species, apart from C. arguta and C. azorica, have been noted in Poland [4].

The genus Calypogeia is considered by many taxonomists as a very difficult group of liverworts $[2,4]$. Simple morphological structure of gametophyte with limited number of diagnostic characters is the main reason of taxonomic problems in liverworts, including Calypogeia [5]. Liverwort taxonomists have at their disposal only the limited number of good diagnostic qualitative traits. Overwhelming majority of features available for study are quantitative (meristic) traits which have continuous phenotypic range. The quantitative traits are often polygenic and may be also significantly influenced by environmental factors, hence, in some cases,

*Corresponding author. Email: androsac@amu.edu.pl

This is an Open Access digital version of the article distributed under the terms of the Creative Commons Attribution 3.0 License (creativecommons.org/licenses/by/3.0/), which permits redistribution, commercial and non-commercial, provided that the article is properly cited. diagnostic differences between species can be overlooked. For this reason, some species described last century on the basis of morphological criteria were too broadly defined and include previously unrecognized species, e.g. Conocephalum salebrosum [6]. Nowadays liverwort taxonomists are aware that diagnostic characters should have a genetic basis [7]. Isozymes, introduced into bryophyte taxonomy, meet the requirements [5]. They are good diagnostic markers that allow to distinguish genetically isolated species (e.g. [8-11]).

Recently, as a result of isozyme studies, species-specific markers have been ascertained for six species of the genus Calypogeia, i.e. C. azurea, C. muelleriana, C. integristipula, C. neesiana, C. suecica and C. sphagnicola. These markers also allow to determine atypical or poorly developed forms that show some modifications of main morphological diagnostic characters $[8,12]$. Application of genetic methods in taxonomic studies of the genus Calypogeia indicates that some unrecognized so far species of this genus might occur in Poland. Thus, the number of Calypogeia species in Europe is probably higher than presently estimated. Isozyme studies, for example, revealed genetic differentiation of C. fissa in Europe into two lineages [13]. Recently, morphological variation of $C$. muelleriana was reported from Poland by Szweykowski [4]. The author detected two forms: typical and atypical. The typical form is widespread in south-western part of Poland, whereas the atypical form occurs in the northern part of lowlands. The preliminary studies revealed differences in morphology of oil bodies between the two forms (unpublished data). This allows to assume that the atypical form of C. muelleriana probably represents a separate taxon. Individuals of the new taxon morphologically resemble C. muelleriana, but they differ from in oil body characteristics and underleaf shape. Oil bodies of the atypical form are bigger and composed of a higher number of segments while underleaves, in contrast to typical 
C. muelleriana, that are protruding from stem, have distinct sinuses and lobes with angulations or teeth. Characters of oil bodies are regarded as features of high taxonomic value [5]. Correlation between isozyme markers and morphological and oil body characters in Calypogeia have been proved [12,13].

The purpose of the present study was to investigate the genetic variation of populations of $C$. muelleriana s.l. with the use of isozyme analysis, to find out whether the typical and atypical forms of $C$. muelleriana are genetically distinct enough to represent separate taxa.

\section{Material and Methods}

\section{Plant material}

Samples of the studied species were collected from different regions of Poland (Tab. 1, Fig. 1). In general, 83 samples from different populations were examined: 58 samples of $C$. muelleriana (34 of the typical and 15 of atypical form) and 28 samples of C. azurea. Since C. azurea is widespread, genetically and morphologically distinct species, well-known and accepted $[2,12,14]$, it was included in this study as a reference species. From each sample (approximately of $100 \mathrm{~cm}^{2}$ ) 4-5 shoots were analyzed, altogether 467 shoots (236 of C. muelleriana: 121 of typical form and 115 of atypical form and 231 of C. azurea). Each sample was divided into 2 parts: one was deposited as a voucher in the POZW Herbarium, while the other was used for analyses. Plants were initially determined on the basis of morphological traits and oil body characters according to Müller [14], Schuster [2] and own observations [15]. Plants classified as the typical form of C. muelleriana exactly correspond to its type specimen [15].

\section{Electrophoretic analysis}

Electrophoretic separation of isozymes was conducted according to the procedure described in detail by Wendel and Weeden [16]. Crude cell extract was prepared by homogenisation of one shoot in $50 \mu \mathrm{l}$ of extraction buffer [17]. Isozymes were separated in $10 \%$ starch gel slabs using three buffer systems: (i) tris-citrate $\mathrm{pH}$ 8.2/lithium-borate $\mathrm{pH}$ 8.3, (ii) morpholine-citrate $\mathrm{pH} 6.1$ in dilution of electrode buffer 1:14 and (iii) tris-histidine pH 7.0 [16]. The enzymes stained and buffer systems used for resolution are listed in the Tab. 2 . After electrophoresis, isoenzymes were detected on gel slabs using standard staining methods [16]. GOT and EST were stained in liquid assay, the remaining enzymes were stained for $2-3$ hours in $37^{\circ} \mathrm{C}$ using the agar-overlay method. In the enzymes with multiple loci, the fastest migrating bands were numbered as 1 and the slower as 2 (i.e. Pgd-1, Pgd-2). Alleles

Tab. 1 Collection sites of the studied populations of C. muelleriana s. 1. and C. azurea (see Fig. 1).

\begin{tabular}{|c|c|c|c|c|}
\hline Population No. & Locality & No. of samples & Collector & Date \\
\hline \multicolumn{5}{|c|}{ C. muelleriana - typical form } \\
\hline 1 & NW Poland, Jez. Orle lake near Miastko & $4+2^{*}$ & $\mathrm{~KB}, \mathrm{AB}$ & 2009.04.15 \\
\hline 2 & NE Poland, Jez. Godle lake near Ełk & $1+1^{*}$ & $\mathrm{~KB}, \mathrm{AB}$ & 2007.08 .05 \\
\hline 3 & Central Poland, Wielkopolskie Province, Antonin near Ostrów Wlkp. & 1 & $\mathrm{~KB}$ & 2009.04.30 \\
\hline 5 & NW Poland, Jez. Lubygość lake near Kartuzy & $4+2^{*}$ & $\mathrm{~KB}, \mathrm{AB}$ & 2009.04 .16 \\
\hline 6 & NW Poland, Jez. Głęboczko lake near Bytów & $1+1^{*}$ & $\mathrm{~KB}, \mathrm{AB}$ & 2009.06.27 \\
\hline 7 & W Poland, Lubuskie Province, Nowogród Bobrzański & 6 & $\mathrm{SR}, \mathrm{KB}$ & 2009.08 .05 \\
\hline 8 & W Poland, Lubuskie Province, Starosiedle foresty & 6 & $\mathrm{SR}, \mathrm{KB}$ & 2009.08.05 \\
\hline 9 & SW Poland, Izerskie Mts, Na Izerze peat bog & 4 & $\mathrm{~KB}, \mathrm{AB}$ & 2006.08 .08 \\
\hline 10 & NW Poland, Jez. Orle lake near Miastko & $1+1^{*}$ & $\mathrm{~KB}, \mathrm{AB}$ & 2009.04.15 \\
\hline 11 & NE Poland, Jez. Godle lake near Ełk & $3+1^{*}$ & $\mathrm{~KB}, \mathrm{AB}$ & 2007.08.05 \\
\hline 12 & NW Poland, Jez. Głęboczko lake near Bytów & 1 & $\mathrm{~KB}, \mathrm{AB}$ & 2009.06.27 \\
\hline 13 & NE Poland, Wigierski National Park, Jez. Sucharek lake near Suwałki & 2 & $\mathrm{~KB}, \mathrm{AB}$ & 2007.08.07 \\
\hline 14 & NW Poland, Jez. Smołowe lake near Miastko & 4 & $\mathrm{~KB}, \mathrm{AB}$ & 2009.06.26 \\
\hline 15 & NW Poland, Jez. Lubygość lake near Kartuzy & 1 & $\mathrm{~KB}, \mathrm{AB}$ & 2009.04.16 \\
\hline 16 & NW Poland, Jez. Jeleń lake near Bytów & 1 & $\mathrm{~KB}, \mathrm{AB}$ & 2009.06 .28 \\
\hline \multicolumn{5}{|l|}{ C. azurea } \\
\hline 17 & S Poland, Tatry Mts, Chowańcówka Stream & 6 & $\mathrm{~KB}, \mathrm{AB}$ & 2006.08 .22 \\
\hline 18 & S Poland, Tatry Mts, E slope of Morske Oko pond & 4 & $\mathrm{~KB}, \mathrm{AB}$ & 2006.09.06 \\
\hline 19 & S Poland, Tatry Mts, Dolina Pańszczycka Valley & 4 & $\mathrm{~KB}, \mathrm{AB}$ & 2006.09.07 \\
\hline 20 & SE Poland, Bieszczady Mts, W slope of Tarnica Mt & 3 & $\mathrm{~KB}, \mathrm{AB}$ & 2008.08.20 \\
\hline 23 & NE Poland, Jez. Godle lake near Ełk & 3 & $\mathrm{~KB}, \mathrm{AB}$ & 2007.08.05 \\
\hline
\end{tabular}

AB - Alina Bączkiewicz; KB - Katarzyna Buczkowska; SR - Stanisław Rosadziński. * Mixed samples of typical and atypical form. 
Tab. 2 Enzymes, their abbreviations, enzyme commision number according to enzyme nomenclature database [30] and buffer systems.

\begin{tabular}{lccc} 
Enzyme & Abbr. & E.C. & Buffer \\
\hline Esterase & EST & $3.1 .1 .-$ & A \\
Aspartate aminotransferase & GOT & 2.6 .1 .1 & A \\
Glutamate dehydrogenase NAD-dependent & GDH & 1.4 .1 .2 & A \\
Phosphoglucoisomerase & PGI & 1.1 .1 .94 & A \\
Phosphocluconate dehydrogenase & PGD & 1.1 .1 .44 & B \\
Malate dehydrogenase & MDH & 1.1 .1 .37 & B \\
Phosphoglucomutase & PGM & 5.4 .2 .2 & C \\
\hline
\end{tabular}

Abbr. - enzymes abbreviations; E.C. - enzyme commision number.

were labeled according to Buczkowska et al. [12], Buczkowska [13], and new detected alleles were denoted with subsequent numbers (Fig. 2).

\section{Data analysis}

Allele frequencies were calculated for each studied group (both forms of C. muelleriana and C. azurea). Nei's [18] genetic identity $(I)$ and genetic distance $(D)$ were estimated between the populations of each group and between the groups and a UPGMA dendrogram was constructed based on the matrix of genetic distances. Analyses were performed using POPGENE-1.32 [19]. To investigate the genetic structure of populations, an analysis of molecular variance (AMOVA) was done by GENALEX 6.3 [20]. The genetic diversity of C. muelleriana s.l. was partitioned into three levels: between groups (typical and atypical forms), among populations within these two groups, and within populations. The level of genetic differentiation between populations was estimated using $\Phi$ statistics (an analogue to $F$ ). Statistical significance of $\Phi$ statistics was tested by a permutation test, the number of permutations was set to 1000 .

\section{Results}

\section{Isozyme phenotypes}

The ten putative loci in seven enzyme systems were consistently resolved in the studied populations of $C$. muelleriana s.l. and C. azurea. Isozyme phenotypes are given in Fig. 2, Fig. 3. In Got, Est-1, Pgd-2, Mdh-2, besides single-banded patterns, different triple-banded and in Pgm double-banded phenotypes were observed. The double and triple-banded isozyme phenotypes possibly represent heterozygous genotypes. Heterozygous genotypes were also observed in $G d h$, which appeared always as a slightly diffused broad band because of its multiple banded phenotype. In the EST enzyme system, two staining regions were scored, the fastest (Est-1) described previously [12] and the slowest, intensively staining, stable and species specific, which was treated as a new locus Est-2.

\section{Genetic differentiation among groups}

An analysis of 10 isozyme loci revealed that two studied forms of $C$. muelleriana in Poland are genetically different. $C$. muelleriana was found to be polymorphic at nine of the 10 studied loci. The observed variation can be partitioned into two distinct groups tentatively called group A and group B (Tab. 3).

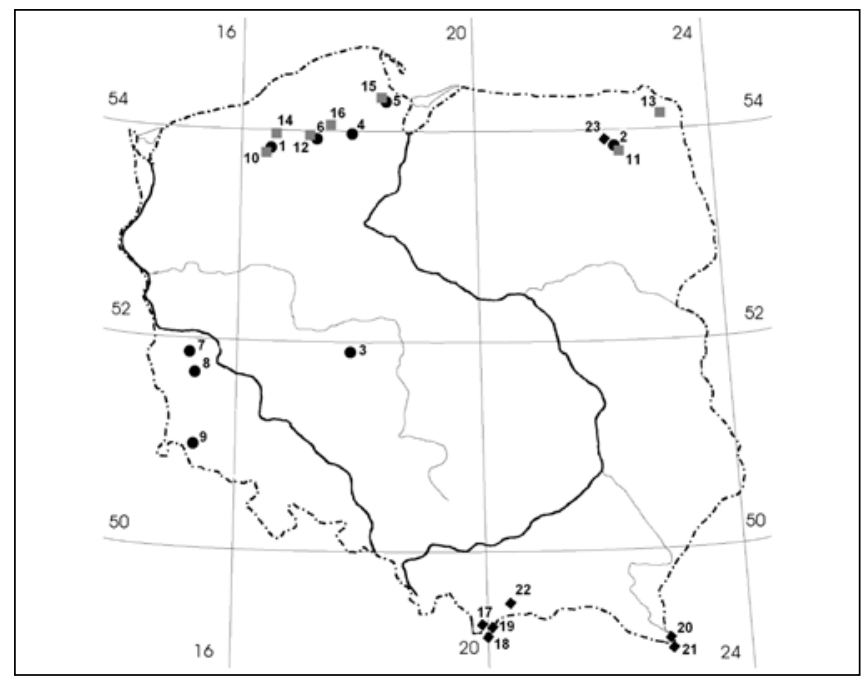

Fig. 1 Map of Poland showing locations of the studied populations of C. muelleriana - typical form (1-9; circles), atypical form (10-16; square), and C. azurea (17-23; panes; see Tab. 1).

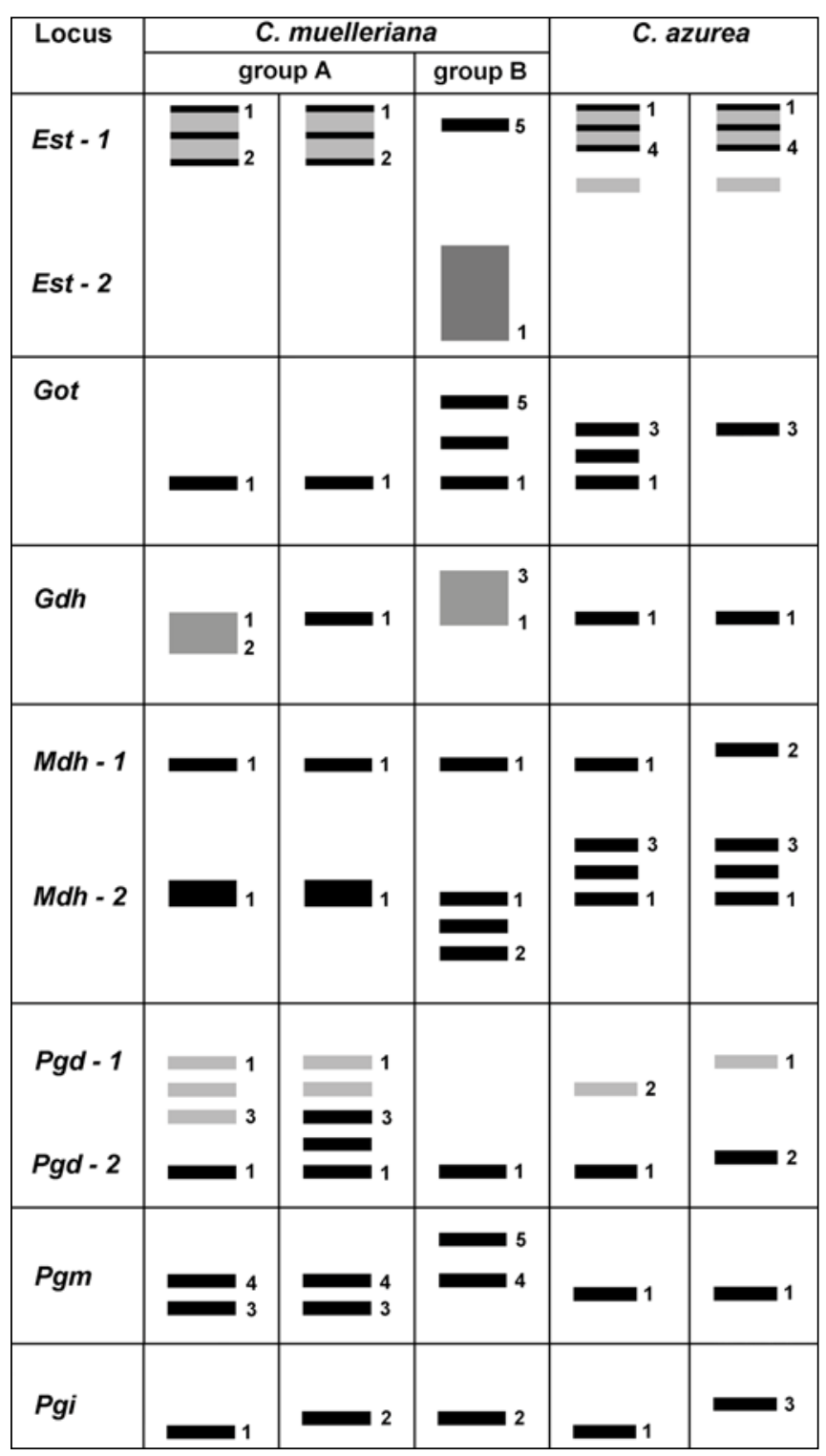

Fig. 2 Scheme of isozyme multilocus phenotypes of two groups of C. muelleriana (A and B) and C. azurea. 

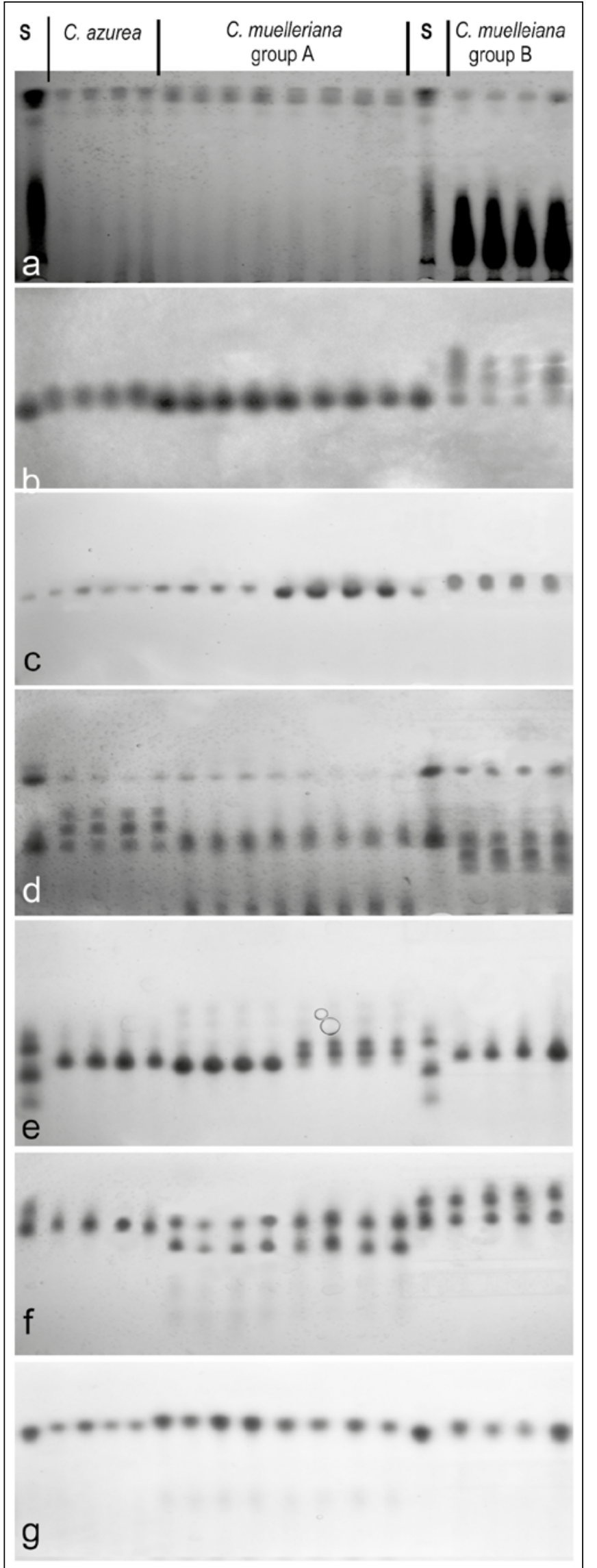

Fig. 3 a-g Isozyme phenotypes of two groups of C. muelleriana (A and B) and C. azurea: a Est; b Got; c Gdh; d Mdh; e Pgd; f Pgm; $\mathbf{g} P g i$. $S$ - standard.
Some loci are perfectly diagnostic for each of the above groups, and some of them, like Got, Est-1, Gdh, Mdh-2 and Pgm show fixed heterozygous pattern in one or both groups (Fig. 2, Fig. 3). For group A, diagnostic alleles are: Got allele 1, Est-1 alleles 12, Mdh-2 allele 1, Pgm alleles 34, for group B: Got alleles 15, Est-1 allele 5, Est-2 allele 1, Gdh alleles 13, Mdh-2 alleles 12 , Pgm alleles 45. Genotypes in particular loci are correlated and composed of multilocus phenotypes (MLP) characteristic for each group. Plants defined as group A correspond to the typical form of C. muelleriana, whereas defined as group B comprise individuals initially determined as the atypical form of $C$. muelleriana and most probably represents a new taxon.

Polymorphism within distinguished groups of C. muelleriana was detected in three loci: Pgd-2, Gdh and Pgi. In group A, two different phenotypes were observed in $P g d-2$ and $G d h$. In Pgd-2, the first triple-banded phenotype was characteristic only

Tab. 3 Allele frequencies for 10 isozyme loci in studied groups of $C$. muelleriana and C. azurea.

\begin{tabular}{|c|c|c|c|c|}
\hline \multirow[t]{2}{*}{ Locus } & \multirow[t]{2}{*}{ Allele $^{1}$} & \multicolumn{2}{|c|}{ C. muelleriana } & \multirow[t]{2}{*}{ C. azurea } \\
\hline & & group A & group B & \\
\hline \multirow[t]{4}{*}{ Est-1 } & 1 & 0.500 & 0.000 & 0.500 \\
\hline & 2 & 0.500 & 0.000 & 0.000 \\
\hline & 4 & 0.000 & 0.000 & 0.500 \\
\hline & 5 & 0.000 & 1.000 & 0.000 \\
\hline \multirow[t]{2}{*}{ Est-2 } & null & 1.000 & 0.000 & 1.000 \\
\hline & 1 & 0.000 & 1.000 & 0.000 \\
\hline \multirow[t]{3}{*}{ Got } & 1 & 1.000 & 0.500 & 0.459 \\
\hline & 3 & 0.000 & 0.000 & 0.541 \\
\hline & 5 & 0.000 & 0.500 & 0.000 \\
\hline \multirow[t]{3}{*}{ Gdh } & 1 & 0.942 & 0.500 & 1.000 \\
\hline & 2 & 0.058 & 0.000 & 0.000 \\
\hline & 3 & 0.000 & 0.500 & 0.000 \\
\hline \multirow[t]{5}{*}{$P g d-1$} & nul & 0.000 & 1.000 & 0.000 \\
\hline & 1 & 0.500 & 0.000 & 0.041 \\
\hline & 2 & 0.000 & 0.000 & 0.936 \\
\hline & 3 & 0.500 & 0.000 & 0.000 \\
\hline & 4 & 0.000 & 0.000 & 0.023 \\
\hline \multirow[t]{3}{*}{$P g d-2$} & 1 & 0.863 & 1.000 & 0.736 \\
\hline & 2 & 0.000 & 0.000 & 0.175 \\
\hline & 3 & 0.138 & 0.000 & 0.088 \\
\hline \multirow[t]{2}{*}{$M d h-1$} & 1 & 1.000 & 1.000 & 0.991 \\
\hline & 2 & 0.000 & 0.000 & 0.009 \\
\hline \multirow[t]{3}{*}{$M d h-2$} & 1 & 1.000 & 0.500 & 0.500 \\
\hline & 2 & 0.000 & 0.500 & 0.000 \\
\hline & 3 & 0.000 & 0.000 & 0.500 \\
\hline \multirow[t]{4}{*}{ Pgm } & 1 & 0.000 & 0.000 & 1.000 \\
\hline & 3 & 0.500 & 0.000 & 0.000 \\
\hline & 4 & 0.500 & 0.500 & 0.000 \\
\hline & 5 & 0.000 & 0.500 & 0.000 \\
\hline \multirow[t]{4}{*}{$P g i$} & 1 & 0.000 & 0.000 & 0.009 \\
\hline & 2 & 0.675 & 0.553 & 0.245 \\
\hline & 3 & 0.283 & 0.316 & 0.732 \\
\hline & 4 & 0.042 & 0.132 & 0.014 \\
\hline $\mathrm{N}$ & & 121 & 115 & 231 \\
\hline
\end{tabular}

${ }^{1}$ Alleles were labeled according to Buczkowska et al. [12], Buczkowska [13], and new detected alleles were denoted with subsequent numbers. 
for this group, but the second single-banded phenotype was shared with group B. In $G d h$ both phenotypes were specific for group A. Four alleles were detected for Pgi, but none of them was correlated with the groups.

Both groups of C. muelleriana clearly differ from C. azurea - the species used as a reference group (Fig. 2, Fig. 3). The UPGMA dendrogram based on Nei's genetic distances shows the differentiation of studied populations into three distinct clades, the first, most distinct, comprises 7 populations of group $\mathrm{B}$ of $C$. muelleriana, the second is divided into two subsets, one including group A of $C$. muelleriana, the second populations of C. azurea (Fig. 4). Genetic distance among two groups of $C$. muelleriana $(D=1.093)$ is almost the same as among C. azurea and the newly distinguished group B of $C$. muelleriana $(D=1.060)$. Genetic distance among $C$. azurea and the typical form of $C$. muelleriana (group A) is the lowest $(D=0.628$; Tab. 4$)$.

The analysis of molecular variance (AMOVA) conducted for populations of $C$. muelleriana s.l. revealed that most of the total genetic variation (89\%) was present among groups (A and B). Smaller amount of genetic variation was distributed among populations (5\%) and within populations (6\%). The coefficient

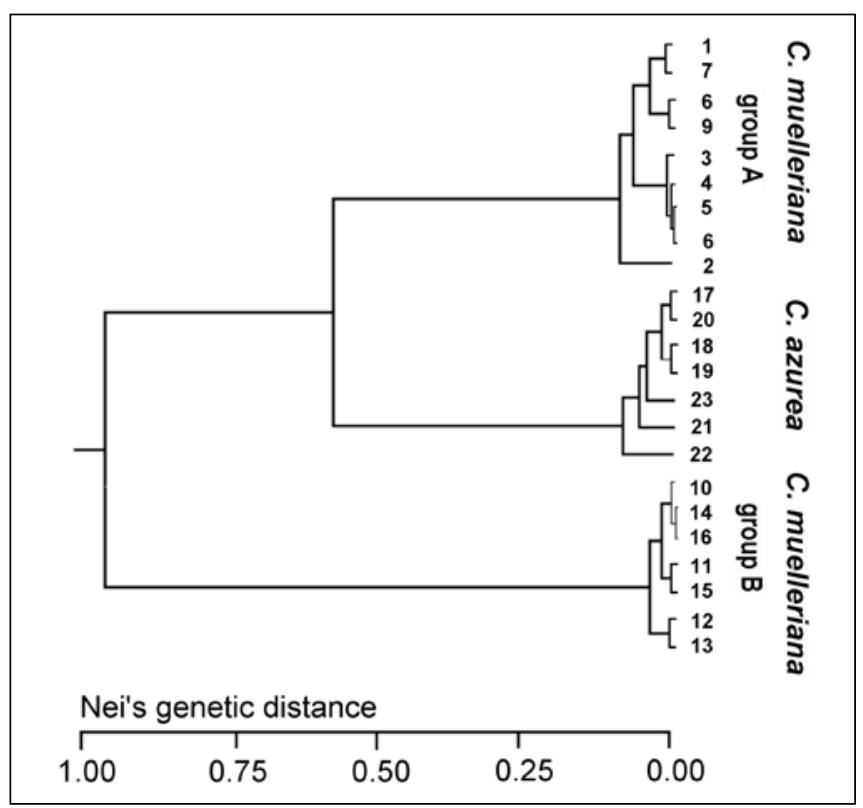

Fig. 4 UPGMA dendrogram based on Nei's [18] genetic distances among populations of two groups of C. muelleriana: group A (1-9), group B (10-16), and C. azurea (17-23). of genetic differentiation was high $\left(\Phi_{\mathrm{RT}}=0.882\right)$ and statistically significant $(P<0.001$; Tab. 5). The coefficient of genetic differentiation $\Phi_{\mathrm{RT}}$ calculated for the pair of C. muelleriana group A and C. azurea was 0.795 and for C. muelleriana group $\mathrm{B}$ and $C$. azurea was 0.870 , and was statistically significant $(P<0.001)$ in both cases. The PCA analysis showed that studied populations form three distinct groups consistent with that distinguished in the dendrogram (Fig. 5). Thus, our analyses confirm the genetic distinctness of two studied forms of $C$. muelleriana.

\section{Discussion}

The results of isozyme studies revealed that the typical and atypical forms of $C$. muelleriana in Poland are clearly genetically different. Beside typical plants that morphologically correspond to the type specimen of C. muelleriana [15], a new, genetically distinct but unrecognized so far taxon, can be distinguished. Each group is defined by several fixed alleles present in all populations. Isozyme phenotypes of a typical form are characteristic to these described previously for $C$. muelleriana [12]. The newly detected group differs from the typical form of $C$. muelleriana in several loci, among others in Est-1, Got and Gdh, which had been already recognized as good diagnostic markers for Calypogeia species [12,13]. These loci were acknowledged as diagnostic markers in many studies (e.g. [11,21,22]). For the genus Calypogeia, the most effective marker was the fastest isozyme of esterase system (Est-1), which allows to identify all species occurring in Poland except for the pair C. suecica - C. neesiana [12]. The fastest isozyme of esterase distinguishes also the newly recognized group of C. muelleriana from its typical form. Moreover, the second isozyme of esterase system Est-2 (the slowest zone) was found to be diagnostic for the studied groups. The other loci regarded as diagnostic markers for Calypogeia species (Got and Gdh) also differentiated two groups of $C$. muelleriana in the present study. Isozyme phenotypes detected in the new group have not been found so far in any of the formerly studied species $[12,13]$.

Isozyme phenotypes of some loci (Got, Gdh, Mdh, Pgm) observed in the newly detected group express fixed heterozygous pattern. This can suggest their allopolyploid origin. Similarly, the typical form of C. muelleriana is a fixed heterozygote at Est-1, Gdh, Pgd and Pgm. The results confirm the allopolyploid origin of $C$. muelleriana that was initially suggested on the basis of Tpi (triose-phosphate isomerase) [12]. Despite the fact that 1276 gametophytes belonging to Calypogeia species that occur in Poland were examined, indication of their parental species

Tab. 4 Nei's [18] genetic distance below diagonal and genetic identity above diagonal between studied groups of C. muelleriana and C. azurea based on gene frequencies from 10 isozyme loci.

\begin{tabular}{|c|c|c|c|}
\hline \multirow[t]{2}{*}{ Taxon } & \multicolumn{2}{|c|}{ C. muelleriana } & \multirow[t]{2}{*}{ C. azurea } \\
\hline & group A & group B & \\
\hline C. muelleriana - group A & $0.066(0.0019-0.169)$ & 0.335 & 0.534 \\
\hline C. muelleriana - group B & 1.093 & $0.028(0.000-0.097)$ & 0.346 \\
\hline C. azurea & 0.628 & 1.060 & $0.067(0.0005-0.197)$ \\
\hline
\end{tabular}

Values on the diagonal are means and ranges of genetic distance for populations within species. 
Tab. 5 Hierarchical analysis of molecular variance (AMOVA) with division of C. muelleriana populations into group A and B.

\begin{tabular}{lccccc}
\hline Source of variation & df & Sum of squares & Variance component & Variance (\%) & Fixation index \\
\hline Among groups & 1 & 360.63 & 3.03 & 88 & $\Phi_{\mathrm{RT}}=0.882^{* * *}$ \\
Among populations within groups & 12 & 39.94 & 0.19 & 5 & $\Phi_{\mathrm{PR}}=0.464^{* * *}$ \\
Within populations & 222 & 48.07 & 0.22 & 6 & $\Phi_{\mathrm{PT}}=0.937^{* * *}$ \\
Total & 235 & 448.64 & 3.43 & 100 & \\
\hline
\end{tabular}

${ }^{1} \Phi_{\mathrm{RT}}$ - variation among groups divided by total variation; $\Phi_{\mathrm{PR}}$ - variation among populations within groups divided by the sum of variation among populations within groups and variation within populations; $\Phi_{\mathrm{PT}}$ - the sum of variation among groups and variation among populations divided by total variation. ${ }^{\star * *} P \leq 0.001$.

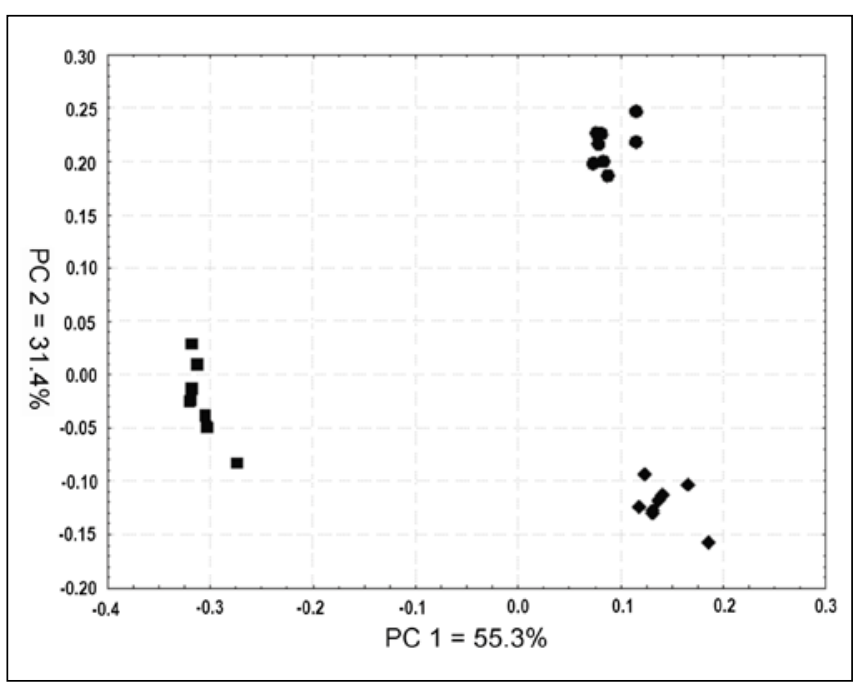

Fig. 5 Two-dimensional scatter plot of PCA based on Nei's [18] genetic distances among populations of two groups of $C$. muelleriana: group A (circles), group B (squares), and C. azurea (panes). The percentage explained variability: PC1 $=55.3 \%$, PC2 $=31.4 \%$.

was impossible so far (unpublished data). However, in order to answer the question about progenitors of allopolyploid Calypogeia species more specimens from a wider range of geographic distribution have to be analyzed. Isozyme studies allowed to indicate progenitor species in the case of Porella baueri [10] and Pellia borealis [23]. In Calypogeia it is especially difficult since the genus comprises about 90 described species [2]. Similarly, the typing of possible parental species was impossible, e.g. in Corsinia [24] and Polytrichastrum [25].

The genetic distance among groups of C. muelleriana (1.093) is higher than between each of the groups and C. azurea (1.060 and 0.628 , respectively), which is a well-known and accepted species. The value is higher than between different liverwort species, e.g. Marchantia polymorpha and M. alpestris (0.450), Plagiochila asplenioides and P. porelloides (0.510) [26], Ptilidium pulcherrimum and P. ciliare (0.739) [27] or Porella platyphylla and $P$. cordeana $I=0.486(D=0.722)[10]$. The mean genetic identity $I$ calculated by Gottlieb [17] for 21 pairs of congeneric plant species was 0.67 , while the mean genetic identity within population of one species was 0.975 , what is the equivalent of genetic distance 0.400 and 0.025 , respectively (according to formula $D=-\ln I$ ). Our results support the hypothesis that the newly distinguished group represents a new taxon of the genus Calypogeia.
The typical form of C. muelleriana occurs mainly in the south-western part of Poland, where it is widespread $[4,12]$, whereas the newly detected taxon is rare. So far, it was found only in seven sites in the lowlands, mainly in the northern and north-eastern parts of Poland. However, more specimens from a wider range of geographic distribution of $C$. muelleriana need to be analyzed before a reliable conclusion can be drawn on the geographic distribution of the new taxon separated from C. muelleriana. Although in the lowlands both groups occur sympatrically, recombinant gametophytes were not observed, even if they occur in mixed patches. This proves the genetic isolation of the new taxon.

The newly detected taxon morphologically resembles $C$. muelleriana. Plants have similar shape of lateral leaves but differ from typical C. muelleriana in underleave shape and oil body characters. These morphological differences, in view of a high morphological plasticity of liverworts, could have been previously interpreted as the environmentally induced variation of $C$. muelleriana. However, the traits that distinguish the above groups are commonly regarded as important in Calypogeia taxonomy $[2,8,13,15]$. Similarly like in other liverworts, but especially in Calypogeia, features of oil bodies are recognized as being of high taxonomic value [28]. In addition, correlation between isoenzyme phenotype and oil body features for Calypogeia species has been proved [8,12,13]. Plants representing the newly detected taxon differ genetically both from C. muelleriana and from other Calypogeia species occurring in Poland. A preliminary biometrical analysis suggests that morphological characters that permit identification of these taxa can also be established [29]. Plants classified as the typical form exactly correspond to the type specimen of $C$. muelleriana [15]. The final taxonomic treatment of the newly distinguished taxon demands future studies.

\section{Acknowledgements}

This work was financially supported by the grant No. N303 344235 from the Polish Ministry of Science and Higher Education. We thank Stanisław Rosadziński (M.Sc.) for help in collecting the plant material used in this study and Patrycja Gonera for help in the laboratory.

\section{References}

1. Bischler H. The genus Calypogeia Raddi in Central and South America. I-III. Candollea. 1963;18:19-128. 
2. Schuster RM. Hepaticae and Anthocerotae of North America East of the Hundredth Meridian. New York: Columbia University Press; 1969. (vol 2).

3. Grolle R, Long DG. An annotated check-list of the Hepaticae and Anthocerotae of Europe and Macaronesia. J Bryol. 2000;22:103-140.

4. Szweykowski J. An annotated checklist of Polish liverworts. Kraków: W. Szafer Institute of Botany, Polish Academy of Sciences; 2006. (Biodiversity of Poland; vol 4).

5. Szweykowski J. Species problems and taxomonic methods in Bryophytes. In: Schuster RM, editor. The new manual of bryology. Nichinan, Japan: Hattori Botanical Laboratory; 1984. p. 1130-1171. (vol 2).

6. Szweykowski J, Buczkowska K, Odrzykoski IJ. Conocephalum salebrosum (Marchantiopsida, Conocephalaceae) - a new Holarctic liverwort species. Plant Syst Evol. 2005;253:133-158. http://dx.doi.org/10.1007/ s00606-005-0301-0

7. Bischler H, Boisselier-Dubayle MC. New approaches to the systematics of liverworts. Nova Hedw. 2000;70:37-44.

8. Szweykowski J, Krzakowa M. Peroxidases as taxonomic markers for some Calypogeia species collected in Poland. Nova Hedw. 1990;51:241-255.

9. Krzakowa M, Szweykowski J, Bisang I, Kozlicka M. Peroxidases as taxonomic characters in Lophozia incisa (Schrad.) Dum. and Lophozia opacifolia (Culm.) Meyl. J Bryol. 1991;16:551-559.

10. Boisselier-Dubayle MC, Lambourdiere J, Bischler H. The leafy liverwort Porella baueri (Porellaceae) is an allopolyploid. Plant Syst Evol. 1998;210:175-197. http://dx.doi. org/10.1007/BF00985667

11. Bączkiewicz A, Buczkowska K. Genetic variability of the Aneura pinguis complex (Hepaticae) in central and western Europe. Biological Lett. 2005;42(1):61-72.

12. Buczkowska K, Odrzykoski IJ, Chudzińska E. Delimitation of some European species of Calypogeia Raddi (Hepaticae, Jungermnniales) based on cytological characters of oil bodies and multienzyme phenotype. Nova Hedw. 2004;78:147163. http://dx.doi.org/10.1127/0029-5035/2004/0078-0147

13. Buczkowska K. Genetic differentiation of Calypogeia fissa (L.) Raddi (Hepaticae, Jungermanniales) in Poland. Plant Syst Evol. 2004;247:187-201. http://dx.doi.org/10.1007/ s00606-003-0156-9

14. Müller K. Kryptogamen Flora von Deutschland, Oesterreich und der Schweiz. 3rd ed. Leipzig: Akademische Verlagsgesellschaft Geest \& Portig; 1957. (vol 6).

15. Buczkowska K. The genus Calypogeia Raddi (Hepaticae, Jungermanniales) in Poland, biometrical analysis of morphological and anatomical variation. Nova Hedw. 2004;78:121-146. http://dx.doi. org/10.1127/0029-5035/2004/0078-0121

16. Wendel JE, Weeden NF. Visualisation and interpretation of plant isozymes. In: Soltis DE, Soltis PS, editors. Isozymes in plant biology. Portland, Oregon: Dioscorides Press;
1989. p. 4-45.

17. Gottlieb LD. Electrophoretic evidence and plant populations. Prog Phytochem. 1981;7:1-46.

18. Nei M. Estimation of average heterozygosity and genetic distance from a small number of individuals. Genetics. 1978;89(3):583-590.

19. Yeh F, Yang R, Boyle T. POPGENE version 1.32. Microsoftbased freeware for population genetic analysis. Canada: Molecular Biology and Biotechnology Center, University of Alberta; 1999.

20. Peakall R, Smouse PE. GENALEX 6: genetic analysis in Excel. Population genetic software for teaching and research. Mol Ecol Notes. 2006;6(1):288-295. http://dx.doi. org/10.1111/j.1471-8286.2005.01155.x

21. Boisselier-Dubayle MC, Jubier MF, Lejeune B, Bischler H. Genetic variability in the three subspecies of Marchantia polymorpha (Hepaticae): isozymes, RFLP and RAPD markers. Taxon. 1995;44(3):363-376. http://dx.doi. org/10.2307/1223406

22. Boisselier-Dubayle MC, Lambourdiere J, Bischler H. Taxa delimitation in Reboulia investigated with morphological, cytological, and isozyme markers. Bryologist. 1998;101(1):61-69. http://dx.doi.org/10.2307/3244074

23. Odrzykoski IJ, Chudzińska E, Szweykowski J. The hybrid origin of the polyploid liverwort Pellia borealis. Genetica. 1996;98:75-86. http://dx.doi.org/10.1007/BF00120221

24. Boisselier-Dubayle MC, Bischler H. Allopolyploidy in the thalloid liverwort Corsinia (Marchantiales). Bot Acta. 1998;111:490-496.

25. Derda GS, Wyatt R. Isozyme evidence regarding the origins of three allopolyploid species of Polytrichastrum (Polytrichaceae, Bryophyta). Plant Syst Evol. 2000;220:37-53. http://dx.doi.org/10.1007/BF00985369

26. Szweykowski J, Odrzykoski IJ. Chemical differentiation of Aneura pinguis (L.) Dum. (Hepaticae, Aneuraceae) in Poland and some comments on application of enzymatic markers in bryology. In: Zinsmeister HD, Mues R, editors. Bryophytes their chemistry and chemical taxonomy. Oxford: Clarendon Press; 1990. p. 437-448.

27. Adamczak, Buczkowska K, Baczkiewicz A, Wachowiak W. Comparison of allozyme variability in Polish populations of two species of Ptilidium Nees (Hepaticae) with contrasting degrees of sexual reproduction. Cryptogamie Bryol. 2005;26(2):151-165.

28. Buch H. Vorarbeiten zu einer Lebermoosflora FennoScandias III. Die Gattung Calypogeia Raddi. Mem Soc F Fl Fenn. 1935;11:197-214.

29. Buczkowska K. Morphological differentiation of Calypogeia muelleriana (Jungermanniales, Hepaticae) in Poland. Biodiv Res Conserv. 2010;17:23-32. http://dx.doi.org/10.2478/ v10119-010-0004-4

30. Enzyme [Internet]. Enzyme nomenclature database. 2010 [cited 2010 Aug 8]; Available from: http://www.expasy.ch/ enzyme/ 